NASA/TM-2000-209891, Vol. 216

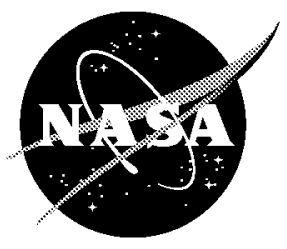

Technical Report Series on the Boreal Ecosystem-Atmosphere Study (BOREAS)

Forrest G. Hall and David E. Knapp, Editors

\title{
Volume 216
}

BOREAS TF-11 SSA-Fen

Soil Surface $\mathrm{CO}_{2}$ Flux Data

Timothy J. Arkebauer

University of Nebraska-Lincoln

National Aeronautics and

Space Administration

Goddard Space Flight Center

Greenbelt, Maryland 20771 
The NASA STI Program Office ... in Profile

Since its founding, NASA has been dedicated to the advancement of aeronautics and space science. The NASA Scientific and Technical Information (STI) Program Office plays a key part in helping NASA maintain this important role.

The NASA STI Program Office is operated by Langley Research Center, the lead center for NASA's scientific and technical information. The NASA STI Program Office provides access to the NASA STI Database, the largest collection of aeronautical and space science STI in the world. The Program Office is also NASA's institutional mechanism for disseminating the results of its research and development activities. These results are published by NASA in the NASA STI Report Series, which includes the following report types:

- TECHNICAL PUBLICATION. Reports of completed research or a major significant phase of research that present the results of NASA programs and include extensive data or theoretical analysis. Includes compilations of significant scientific and technical data and information deemed to be of continuing reference value. NASA's counterpart of peer-reviewed formal professional papers but has less stringent limitations on manuscript length and extent of graphic presentations.

- TECHNICAL MEMORANDUM. Scientific and technical findings that are preliminary or of specialized interest, e.g., quick release reports, working papers, and bibliographies that contain minimal annotation. Does not contain extensive analysis.

- CONTRACTOR REPORT. Scientific and technical findings by NASA-sponsored contractors and grantees.
- CONFERENCE PUBLICATION. Collected papers from scientific and technical conferences, symposia, seminars, or other meetings sponsored or cosponsored by NASA.

- SPECIAL PUBLICATION. Scientific, technical, or historical information from NASA programs, projects, and mission, often concerned with subjects having substantial public interest.

- TECHNICAL TRANSLATION. English-language translations of foreign scientific and technical material pertinent to NASA's mission.

Specialized services that complement the STI Program Office's diverse offerings include creating custom thesauri, building customized databases, organizing and publishing research results ... even providing videos.

For more information about the NASA STI Program Office, see the following:

- Access the NASA STI Program Home Page at http://www.sti.nasa.gov/STI-homepage.html

- E-mail your question via the Internet to help@sti.nasa.gov

- Fax your question to the NASA Access Help Desk at (301) 621-0134

- Telephone the NASA Access Help Desk at (301) 621-0390

- Write to:

NASA Access Help Desk

NASA Center for AeroSpace Information 7121 Standard Drive Hanover, MD 21076-1320 
NASA/TM-2000-209891, Vol. 216

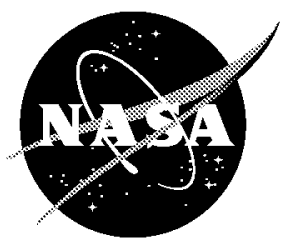

Technical Report Series on the Boreal Ecosystem-Atmosphere Study (BOREAS)

Forrest G. Hall and David E. Knapp, Editors

\section{Volume 216}

BOREAS TF-11 SSA-Fen

Soil Surface $\mathrm{CO}_{2}$ Flux Data

Timothy J. Arkebauer

University of Nebraska-Lincoln

National Aeronautics and

Space Administration

Goddard Space Flight Center

Greenbelt, Maryland 20771 


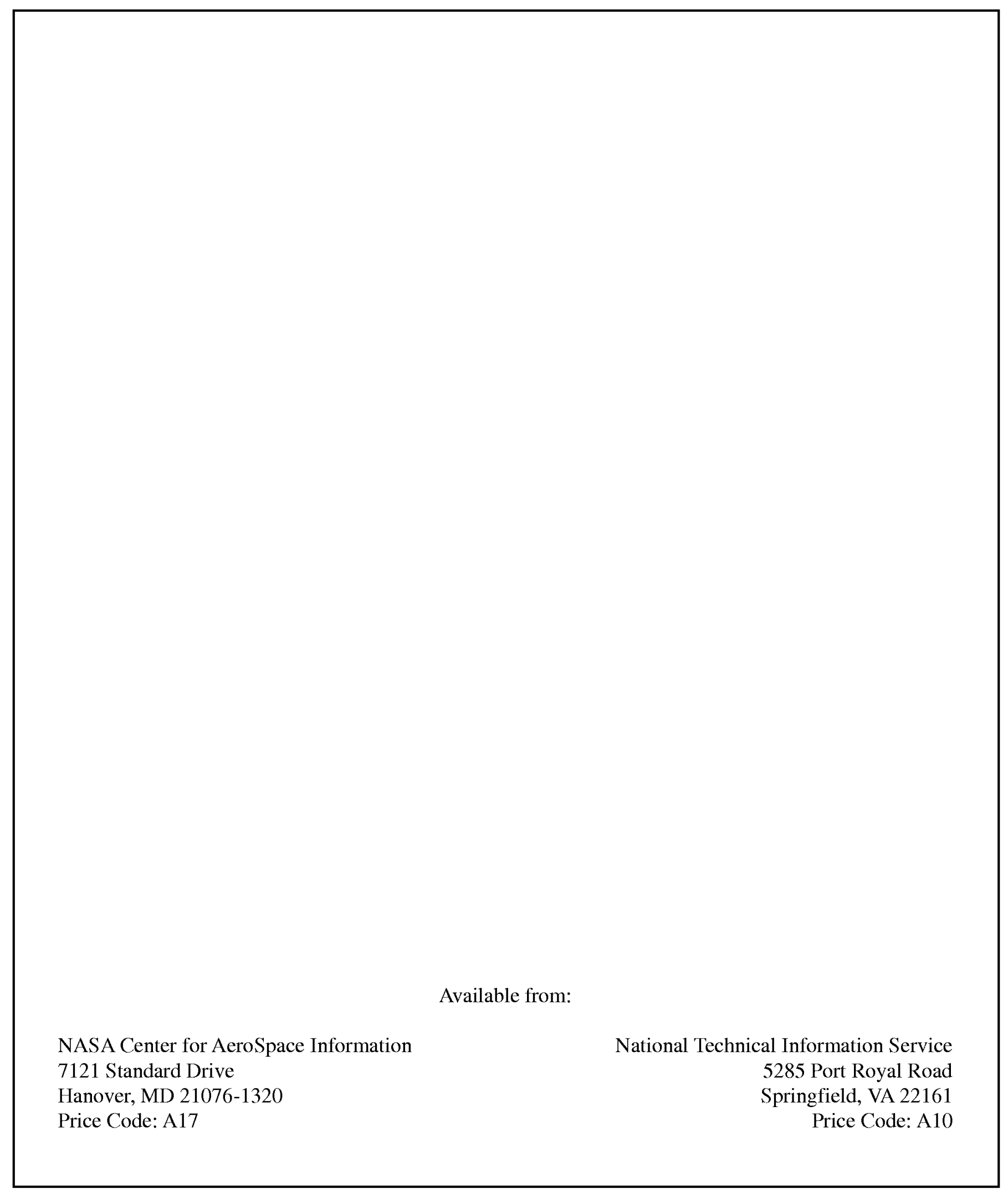




\section{BOREAS TF-11 SSA-Fen Soil Surface $\mathrm{CO}_{2}$ Flux Data}

Timothy J. Arkebauer

\section{Summary}

The BOREAS TF-11 team gathered a variety of data to complement its tower flux measurements collected at the SSA-Fen site. These data are soil surface $\mathrm{CO}_{2}$ flux data at the SSA-Fen site from 27-May-1994 to 23-Sep-1994 and from 13-May-1995 to 03-Oct-1995. A portable gas exchange system was used to make these measurements. The data are stored in tabular ASCII files.

\section{Table of Contents}

1) Data Set Overview

2) Investigator(s)

3) Theory of Measurements

4) Equipment

5) Data Acquisition Methods

6) Observations

7) Data Description

8) Data Organization

9) Data Manipulations

10) Errors

11) Notes

12) Application of the Data Set

13) Future Modifications and Plans

14) Software

15) Data Access

16) Output Products and Availability

17) References

18) Glossary of Terms

19) List of Acronyms

20) Document Information

\section{Data Set Overview}

\subsection{Data Set Identification}

BOREAS TF-11 SSA-Fen Soil Surface $\mathrm{CO}_{2}$ Flux Data

\subsection{Data Set Introduction}

The Tower Flux (TF)-11 team collected soil surface $\mathrm{CO}_{2}$ flux data at the BOReal Ecosystem-Atmosphere Study (BOREAS) Southern Study Area (SSA)-Fen site in 1994 and 1995. A portable gas exchange system was used to make these measurements.

\subsection{Objectives/Purpose}

The objective of these measurements was to evaluate the soil surface $\mathrm{CO}_{2}$ flux and characterize its response to controlling variables (e.g., temperature, water content, water table depth).

\subsection{Summary of Parameters}

Each data record includes the date and time of measurements, surface $\mathrm{CO}_{2}$ flux, and environmental conditions (air temperature, soil temperature, $\mathrm{CO}_{2}$ concentration, relative humidity, and air vapor pressure). 


\subsection{Discussion}

The overall project goal was to investigate the surface-atmosphere exchange of carbon dioxide and methane, and the associated energy fluxes, at the SSA-Fen site. The exchange of $\mathrm{CO}_{2}$ at the soil surface is an important component of the overall surface-atmosphere $\mathrm{CO}_{2}$ exchange. It is related to soil (peat) decomposition processes, long-term carbon storage, and, perhaps more indirectly, canopy photosynthesis.

\subsection{Related Data Sets}

BOREAS TF-11 SSA-Fen Tower Flux and Meteorological Data

BOREAS TF-11 SSA-Fen Leaf Gas Exchange Data

BOREAS TF-11 SSA-Fen 1995 Leaf Area Index Data

BOREAS TF-11 SSA-Fen 1996 Water Surface Film Capping Data

\section{Investigator(s)}

\subsection{Investigator(s) Name and Title}

Dr. Timothy J. Arkebauer, Associate Professor

Department of Agronomy

University of Nebraska-Lincoln

Dr. Shashi B. Verma, Professor

Department of Agricultural Meteorology

University of Nebraska-Lincoln

\subsection{Title of Investigation}

Field Micrometeorological Measurements, Process-Level Studies and Modeling of Methane and Carbon Dioxide Fluxes in a Boreal Wetland Ecosystem

\subsection{Contact Information}

\section{Contact 1:}

Dr. Timothy J. Arkebauer

Department of Agronomy

106 KCR Building

University of Nebraska

Lincoln NE 68583-0817 USA

(402) 472-2847

\section{Contact 2:}

David Knapp

Raytheon ITSS

NASA GSFC

Code 923

Greenbelt, MD 20771

(301) 286-1424

(301) 286-0239 (fax)

David.Knapp@gsfc.nasa.gov 


\section{Theory of Measurements}

Surface $\mathrm{CO}_{2}$ flux measurements were made by using an LI-6200 system in the closed-circuit mode. An LI-6000-09 Soil Respiration Chamber was used with the system. The $\mathrm{CO}_{2}$ flux is calculated via the change in $\mathrm{CO}_{2}$ concentration in the sample chamber with time. Further details can be found in the LI-6200 Technical Reference Manual (LI-COR, Inc., 1990). Additional information on the general theory related to gas exchange measurements can be found in Ball (1987).

\section{Equipment}

\subsection{Instrument Description}

The measurements were made with an LI-6200 Portable Photosynthesis System outfitted with an LI-6000-09 Soil Respiration Chamber. The chamber volume is approximately 1-liter, and it covers 83 $\mathrm{cm}^{2}$ of the soil surface.

\subsubsection{Collection Environment}

All measurements were made under ambient environmental conditions in the field at the SSA-Fen site.

\subsubsection{Source/Platform}

Measurements were made from platforms or boardwalks raised approximately $0.2 \mathrm{~m}$ above the fen surface.

\subsubsection{Source/Platform Mission Objectives}

None given.

\subsubsection{Key Variables}

Soil surface $\mathrm{CO}_{2}$ flux, soil temperature, air temperature, air vapor pressure, air $\mathrm{CO}_{2}$ concentration, distance between soil surface and water table.

\subsubsection{Principles of Operation}

The LI-6200 was operated in the closed mode. Surface $\mathrm{CO}_{2}$ fluxes were determined from the time rate of change of $\mathrm{CO}_{2}$ concentration in the LI-6000-09 chamber. $\mathrm{CO}_{2}$ concentrations are measured with an infrared gas analyzer (IRGA). A pump circulates the air from the respiration chamber, through the analyzer, and back into the chamber. Water vapor concentrations in the sample chamber are determined by a Vaisala humidity chip and a thermistor sensing the air temperature. Soil temperatures are determined by a thermocouple pair that measures the temperature difference between the air thermistor and a thermocouple inserted $10 \mathrm{~cm}$ below the soil surface.

Additional information is found in the LI-COR LI-6200 Technical Reference manual, the LI-COR LI-6000-09 Soil Respiration Chamber instruction manual, and Norman et al. (1992).

\subsubsection{Sensor/Instrument Measurement Geometry}

The measurements were made with an LI-6200 Portable Photosynthesis System outfitted with an LI-6000-09 Soil Respiration Chamber. The chamber volume is approximately 1-liter, and it covers 83 $\mathrm{cm}^{2}$ of the soil surface. 


\subsubsection{Manufacturer of Instrument \\ LI-COR, Inc. \\ P.O. Box 4425 \\ 4421 Superior Street \\ Lincoln, NE 68504 USA \\ (402) 467-3576 \\ (402) 467-2819 (fax)}

\subsection{Calibration}

\subsubsection{Specifications}

The IRGAs, the humidity chips, the flow meters, and the quantum sensors were calibrated by the manufacturer prior to each field season. The zero and span of the LI- $6200 \mathrm{CO}_{2}$ analyzer were calibrated against known standard gases in the field.

\subsubsection{Tolerance}

None given.

\subsubsection{Frequency of Calibration}

Annual calibration of the IRGAs, the humidity chips, the flow meters, and the quantum sensors were done by the manufacturer. Daily calibration of the zero and span of the IRGAs was done in the field. The $\mathrm{CO}_{2}$ zero and the flow meter zero were checked and adjusted several times daily.

\subsubsection{Other Calibration Information}

Calibration gases for the IRGAs were obtained from:

Acklands

1042 Quebec Ave.

Saskatoon, Saskatchewan CANADA, S7K 1V5

(Primary supplier: Linde gas, Alberta, CANADA)

These gases were calibrated against gases of known concentration traceable to the National Oceanic and Atmospheric Administration (NOAA), Boulder, CO.

\section{Data Acquisition Methods}

The surface $\mathrm{CO}_{2}$ fluxes were measured at 48 collar locations (see Section 7.1.1). These collars were positioned in early May each year and were not moved during the growing season. When the water table covered a collar, the measurement was made at the water surface above the collar.

For each surface flux determination, the LI-6000-09 chamber was first positioned atop the polyvinylchloride (PVC) collar such that a good seal was obtained. A tripod was used to hold the chamber in position. Fluxes were determined from the change of $\mathrm{CO}_{2}$ concentration inside the closed system. Care was taken to determine fluxes when the $\mathrm{CO}_{2}$ concentration in the chamber was near ambient (ca. $350 \mathrm{ppm}$ ); at times this meant drawing down the system $\mathrm{CO}_{2}$ concentration by using the LI-6200 soda lime scrubber. Once the chamber was in place, individual measurements took about 1 minute to complete.

A negative surface $\mathrm{CO}_{2}$ flux (e.g., soil respiration) indicates that the net flux of $\mathrm{CO}_{2}$ is from the soil into the atmosphere. 


\section{Observations}

\subsection{Data Notes}

None given.

\subsection{Field Notes}

A limited set of field notes and observations is available by request from T.J. Arkebauer (see Section 2.3).

\section{Data Description}

\subsection{Spatial Characteristics}

\subsubsection{Spatial Coverage}

The SSA-Fen is a "patterned" fen with a heterogenous surface. Areas of open water alternate with 2- to 20-cm-tall hummocks composed of more or less consolidated vegetation. Larger features include strings, where the peat surface is about $20-50 \mathrm{~cm}$ above the water table, and flarks, which are more extensive areas of open water. We attempted to characterize the variability in the surface $\mathrm{CO}_{2}$ flux associated with these microtopographic features as well as to obtain estimates of the surface $\mathrm{CO}_{2}$ flux in the vicinity of the micrometeorological tower.

In mid-August 1993, two permanent boardwalks were laid out about $200 \mathrm{~m}$ north and south of the main (eddy correlation) boardwalk. Twelve measurement platforms were erected along each boardwalk to allow us access to the fen surface without standing on it. Six of these platforms (N1, $\mathrm{N}_{2}, \mathrm{~S} 1, \mathrm{~S} 2$, S5, and S6) were located on obvious (i.e., large) strings. (Note that these larger strings were, for the most part, absent from the "micrometeorological footprint" sensed by the eddy correlation sensors.) All the 1994 and 1995 surface flux data were obtained adjacent to these platforms. Platforms N3, N4, $\mathrm{N} 5, \mathrm{~N} 6, \mathrm{~S} 3$, and S4 were judged to be most representative of the micrometeorological tower footprint. These six platforms were all located in extensive areas of Betula pumila. The surface here consisted of sedge (Carex sp.) hummocks interspersed with open water where Menyanthes trifoliata was common.

At the beginning of each season, $48 \mathrm{PVC}$ collars (about $10 \mathrm{~cm}$ in diameter and $10 \mathrm{~cm}$ long) were placed near the 12 access platforms (four at each platform). Each of the four were positioned so that one collar was in a low spot, one was on a high spot, and two were in between. As the water table position changed during the season, the collars were alternately inundated and exposed.

The SSA-Fen tower was located at the following North American Datum of 1983 (NAD83) coordinates:

\begin{tabular}{|c|c|c|c|c|c|}
\hline itude & Longitude & BOREAS_X & BOREAS_Y & UTM Northing & UTM Easting \\
\hline${ }^{\circ} \mathrm{N}$ & 104.617 & 419.527 & 330.991 & 66. & \\
\hline
\end{tabular}

\subsubsection{Spatial Coverage Map}

Not available.

\subsubsection{Spatial Resolution}

Each measurement represents the flux at a 10-cm-diameter area near the SSA-Fen tower site.

\subsubsection{Projection}

These data were collected at point locations.

\subsubsection{Grid Description}

None. 


\subsection{Temporal Characteristics}

\subsubsection{Temporal Coverage}

Measurements were made from 27-May-1994 to 23-Sep-1994 and from 13-May-1995 to 03-Oct-1995.

\subsubsection{Temporal Coverage Map}

None.

\subsubsection{Temporal Resolution}

Measurements were taken at multiple times during the growing seasons.

\subsection{Data Characteristics}

\subsubsection{Parameter/Variable}

The parameters contained in the data files on the CD-ROM are:

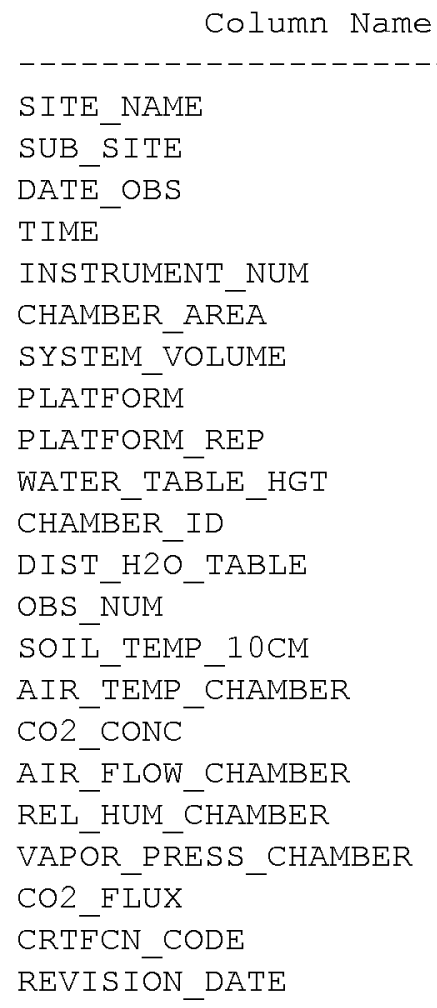




\subsubsection{Variable Description/Definition}

The descriptions of the parameters contained in the data files on the CD-ROM are:

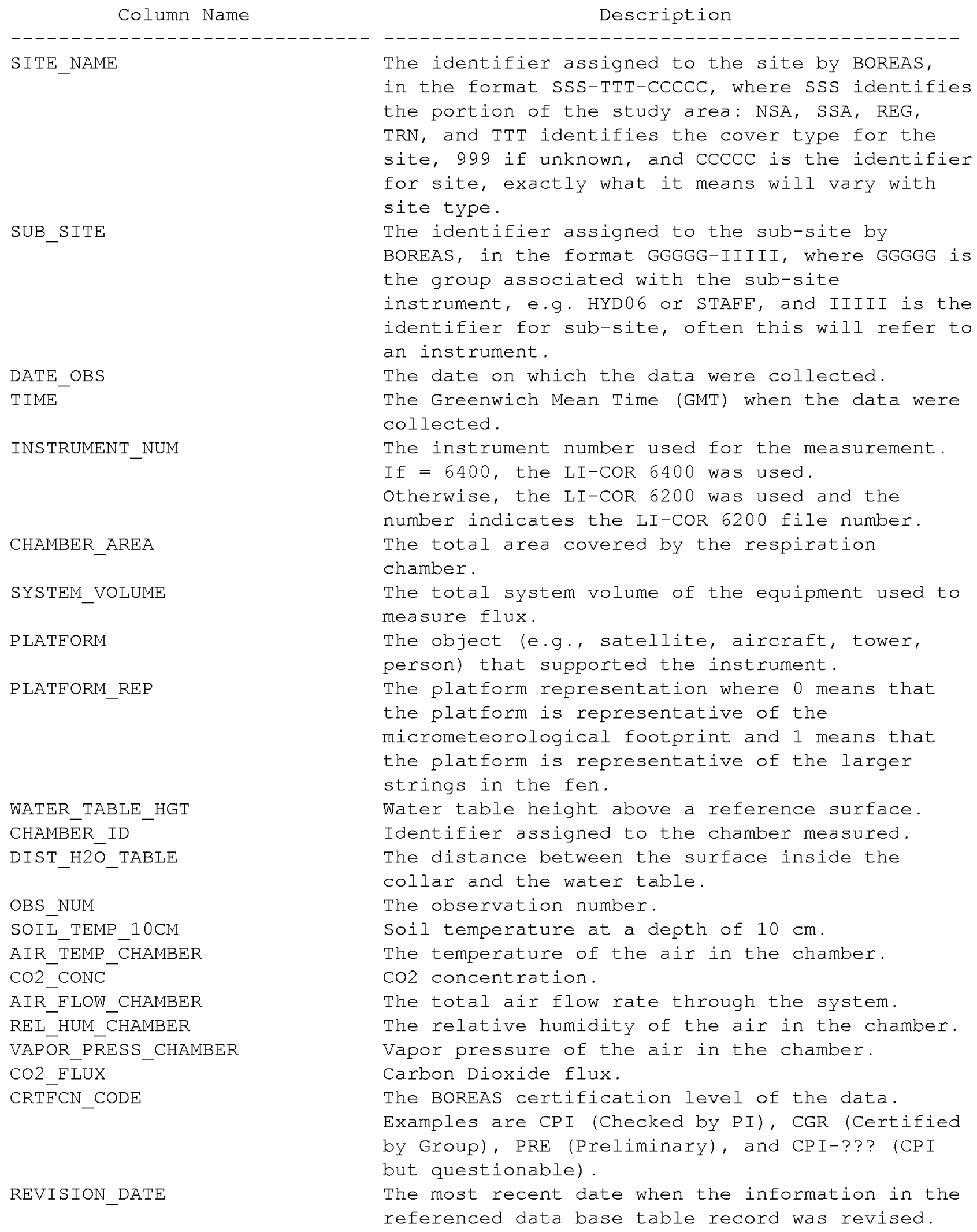

Page 7 


\subsubsection{Unit of Measurement}

The measurement units for the parameters contained in the data files on the CD-ROM are:

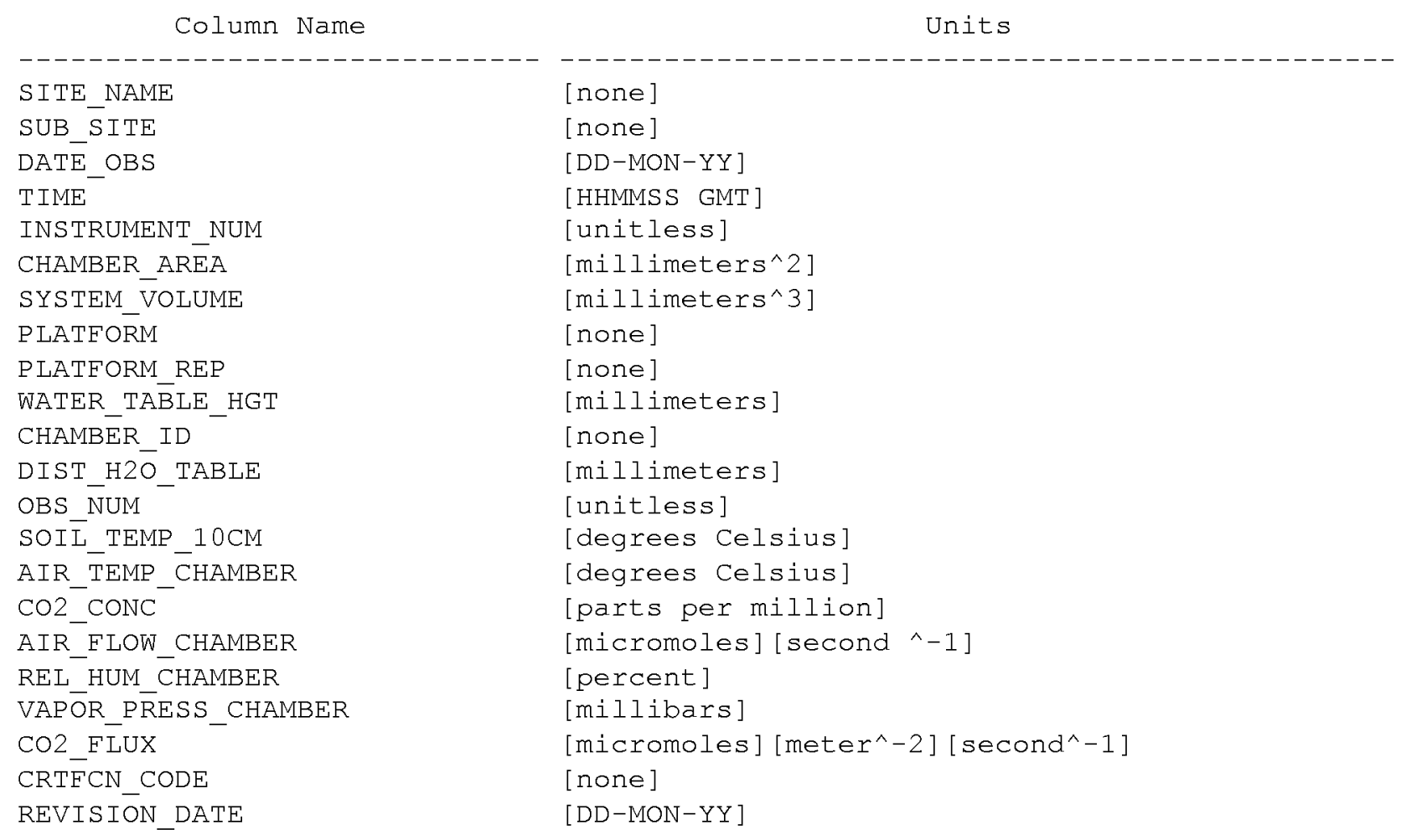

7.3.4 Data Source

The sources of the parameter values contained in the data files on the CD-ROM are:

Column Name

SITE_NAME
SUB_SITE
DATE_OBS
TIME
INSTRUMENT_NUM
CHAMBER_AREA
SYSTEM_VOLUME
PLATFORM
PLATEORM_REP
WATER_TABLE_HGT
CHAMBER_ID
DIST_H2O_TABLE
OBS_EUM
SOIL_TEMP_1OCM
AIR_TEMP_CHAMBER
CO2_CONC
AIR_FLOW_CHAMBER
REL_HUM_CHAMBER
VAPOR_PRESS_CHAMBER
CO2_FLUX
CRTFCN_CODE
REVISION_DATE

Data Source 
7.3.5 Data Range

The following table gives information about the parameter values found in the data files on the CD-ROM.

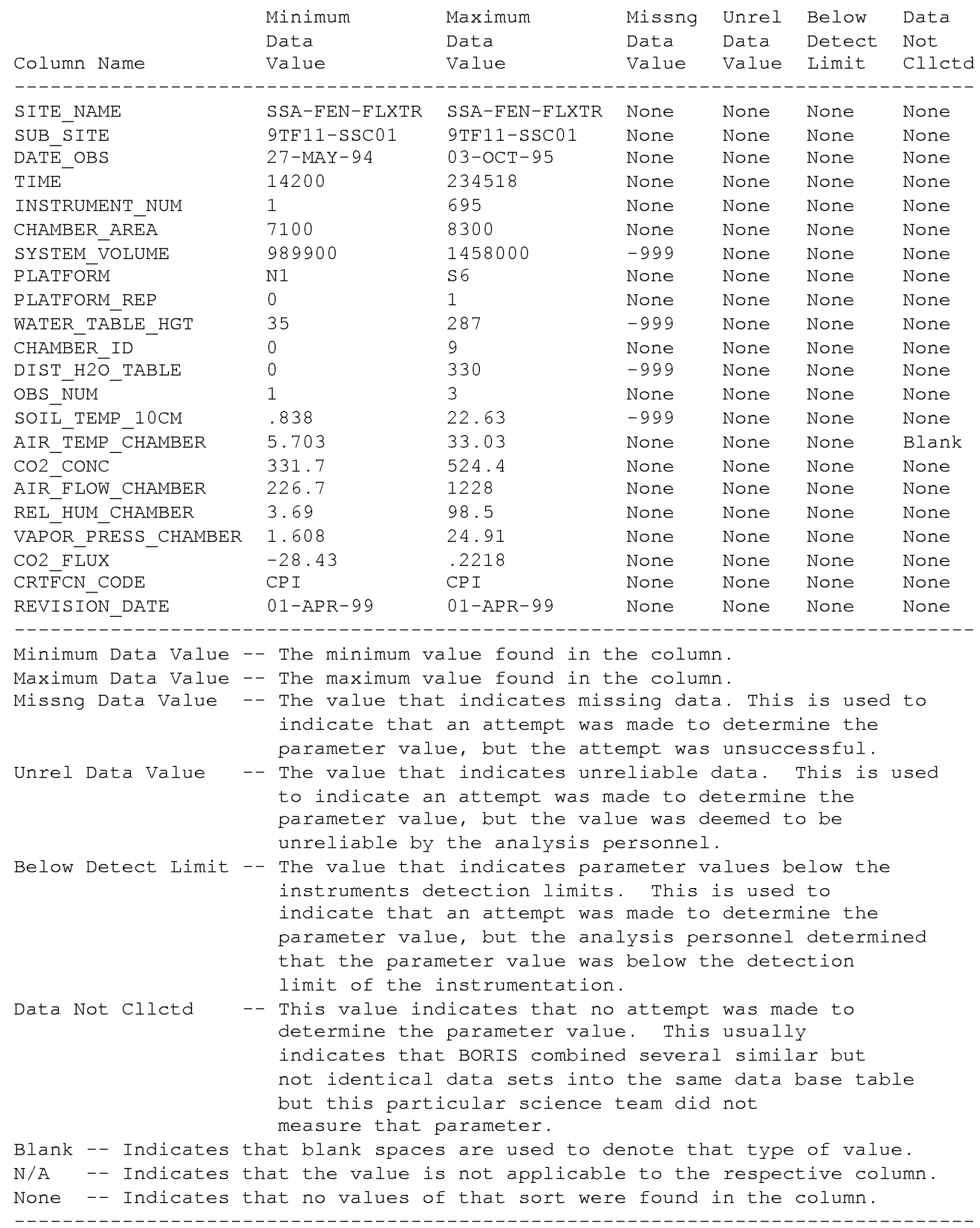

\section{Page 9}




\subsection{Sample Data Record}

The following are wrapped versions of data record from a sample data file on the CD-ROM.

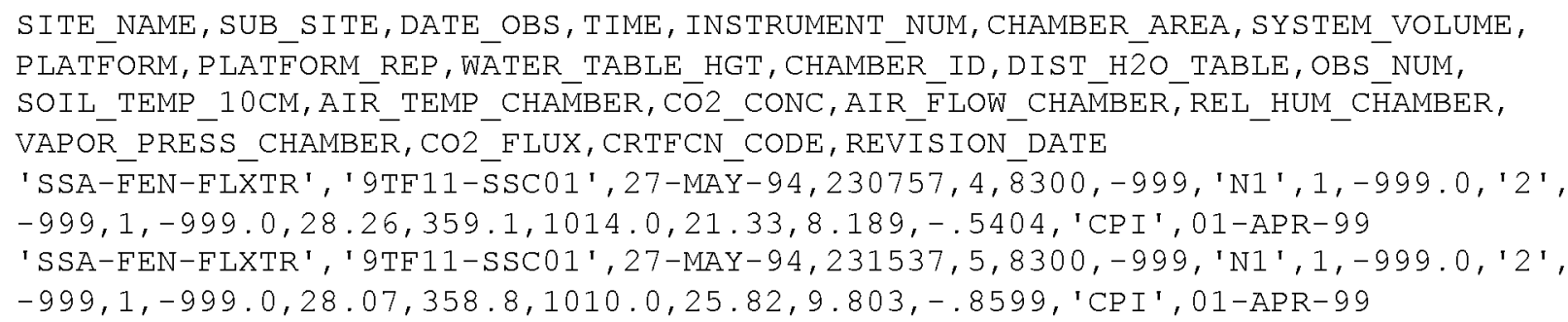

\section{Data Organization}

\subsection{Data Granularity}

The smallest amount of data that can be ordered from this data set is a day's worth of data for a given site.

\subsection{Data Format}

The Compact Disk-Read-Only Memory (CD-ROM) files contain American Standard Code for Information Interchange (ASCII) numerical and character fields of varying length separated by commas. The character fields are enclosed with single apostrophe marks. There are no spaces between the fields.

Each data file on the CD-ROM has four header lines of Hyper-Text Markup Language (HTML) code at the top. When viewed with a Web browser, this code displays header information (data set title, location, date, acknowledgments, etc.) and a series of HTML links to associated data files and related data sets. Line 5 of each data file is a list of the column names, and line 6 and following lines contain the actual data.

\section{Data Manipulations}

\subsection{Formulae}

Formulae for calculating the $\mathrm{CO}_{2}$ flux rates are given in the LI-6200 Technical Reference Manual.

\subsubsection{Derivation Techniques and Algorithms}

None given.

\subsection{Data Processing Sequence}

\subsubsection{Processing Steps}

- $\quad$ The BOREAS Information System (BORIS) received data from TF-11.

- $\quad$ BORIS standardized the units and loaded data into the data base.

- $\quad$ BORIS extracted data from database into ASCII files.

\subsubsection{Processing Changes}

None.

\subsection{Calculations}

None.

\subsubsection{Special Corrections/Adjustments}

None. 


\subsubsection{Calculated Variables}

None.

9.4 Graphs and Plots

None.

\section{Errors}

\subsection{Sources of Error}

Calibration drift: The flow meter zero and IRGA $\mathrm{CO}_{2}$ zero exhibited occasional drifts. The zeros were set periodically throughout the day.

\subsection{Quality Assessment}

None given.

10.2.1 Data Validation by Source

None given.

\subsubsection{Confidence Level/Accuracy Judgment}

None given.

\subsubsection{Measurement Error for Parameters}

None given.

\subsubsection{Additional Quality Assessments}

None given.

\subsubsection{Data Verification by Data Center}

BORIS staff loaded the data into the data base and checked for any inconsistencies during loading.

\section{Notes}

\subsection{Limitations of the Data}

None given.

\subsection{Known Problems With The Data}

There were problems with the soil thermocouple probes used in 1994. All 1994 soil temperatures are indicated as missing values. The difficult-to-interpret 1994 soil temperatures may be available by special request from T.J. Arkebauer.

\subsection{Usage Guidance}

The normal caveat of 'use at your own risk' applies. Correspondence with T.J. Arkebauer is encouraged when questions arise. A negative surface $\mathrm{CO}_{2}$ flux (e.g., soil respiration) indicates that the net flux of $\mathrm{CO}_{2}$ is from the soil into the atmosphere.

\subsection{Other Relevant Information}

Dr. Evan C. Jolitz was responsible for much of the day-to-day coordination of the field measurements. Mr. Shawn Stevens and Mr. Tommi Peltovuori assisted in data collection in 1994. Their assistance is greatly appreciated. We also thank LI-COR, Inc., for their generous contribution of various prototypes of the LI-6000-09 respiration chambers. 


\section{Application of the Data Set}

These data can be used to better understand the soil $\mathrm{CO}_{2}$ flux at a typical fen in the boreal forest.

\section{Future Modifications and Plans}

None.

\section{Software}

\subsection{Software Description}

None given.

\subsection{Software Access}

None given.

\section{Data Access}

The SSA-Fen soil surface $\mathrm{CO}_{2}$ flux data are available from the Earth Observing System Data and Information System (EOSDIS) Oak Ridge National Laboratory (ORNL) Distributed Active Archive Center (DAAC).

\subsection{Contact Information}

For BOREAS data and documentation please contact:

ORNL DAAC User Services

Oak Ridge National Laboratory

P.O. Box 2008 MS-6407

Oak Ridge, TN 37831-6407

Phone: (423) 241-3952

Fax: (423) 574-4665

E-mail: ornldaac@ornl.gov or ornl@eos.nasa.gov

\subsection{Data Center Identification}

Earth Observing System Data and Information System (EOSDIS) Oak Ridge National Laboratory (ORNL) Distributed Active Archive Center (DAAC) for Biogeochemical Dynamics http://www-eosdis.ornl.gov/.

\subsection{Procedures for Obtaining Data}

Users may obtain data directly through the ORNL DAAC online search and order system [http://www-eosdis.ornl.gov/] and the anonymous FTP site [ftp://www-eosdis.ornl.gov/data/] or by contacting User Services by electronic mail, telephone, fax, letter, or personal visit using the contact information in Section 15.1.

\subsection{Data Center Status/Plans}

The ORNL DAAC is the primary source for BOREAS field measurement, image, GIS, and hardcopy data products. The BOREAS CD-ROM and data referenced or listed in inventories on the CD-ROM are available from the ORNL DAAC. 


\section{Output Products and Availability}

\subsection{Tape Products}

None.

\subsection{Film Products}

None.

\subsection{Other Products}

These data are available on the BOREAS CD-ROM series.

\section{References}

\subsection{Platform/Sensor/Data Processing Documentation}

LI-6200 Technical Reference Manual. March 1990. LI-COR, Inc., Lincoln NE, USA.

LI-6000-09 Instruction Manual, November 1993. LI-COR, Inc., Lincoln NE, USA.

\subsection{Journal Articles and Study Reports}

Ball, J.T. 1987. Calculations related to gas exchange. In: Stomatal Function. E. Zeiger, G.D.

Farquhar, and I.R. Cowan (eds.). Stanford University Press, Stanford, CA, pp. 446-475.

Newcomer, J., D. Landis, S. Conrad, S. Curd, K. Huemmrich, D. Knapp, A. Morrell, J. Nickeson, A. Papagno, D. Rinker, R. Strub, T. Twine, F. Hall, and P. Sellers, eds. 2000. Collected Data of The Boreal Ecosystem-Atmosphere Study. NASA. CD-ROM.

Norman, J.M., R. Garcia, and S.B. Verma. 1992. Soil surface $\mathrm{CO}_{2}$ fluxes and the carbon budget of a grassland. Journal of Geophysical Research 97(D17): 18,845-18,853.

Sellers, P. and F. Hall. 1994. Boreal Ecosystem-Atmosphere Study: Experiment Plan. Version 1994-3.0, NASA BOREAS Report (EXPLAN 94).

Sellers, P. and F. Hall. 1996. Boreal Ecosystem-Atmosphere Study: Experiment Plan. Version 1996-2.0, NASA BOREAS Report (EXPLAN 96).

Sellers, P., F. Hall, and K.F. Huemmrich. 1996. Boreal Ecosystem-Atmosphere Study: 1994 Operations. NASA BOREAS Report (OPS DOC 94).

Sellers, P., F. Hall, and K.F. Huemmrich. 1997. Boreal Ecosystem-Atmosphere Study: 1996 Operations. NASA BOREAS Report (OPS DOC 96).

Sellers, P., F. Hall, H. Margolis, B. Kelly, D. Baldocchi, G. den Hartog, J. Cihlar, M.G. Ryan, B. Goodison, P. Crill, K.J. Ranson, D. Lettenmaier, and D.E. Wickland. 1995. The boreal ecosystem-atmosphere study (BOREAS): an overview and early results from the 1994 field year. Bulletin of the American Meteorological Society. 76(9):1549-1577.

Sellers, P.J., F.G. Hall, R.D. Kelly, A. Black, D. Baldocchi, J. Berry, M. Ryan, K.J. Ranson, P.M. Crill, D.P. Lettenmaier, H. Margolis, J. Cihlar, J. Newcomer, D. Fitzjarrald, P.G. Jarvis, S.T. Gower, D. Halliwell, D. Williams, B. Goodison, D.E. Wickland, and F.E. Guertin. 1997. BOREAS in 1997: Experiment Overview, Scientific Results and Future Directions. Journal of Geophysical Research 102(D24): 28,731-28,770. 


\subsection{Archive/DBMS Usage Documentation}

None.

\section{Glossary of Terms}

None.

\section{List of Acronyms}

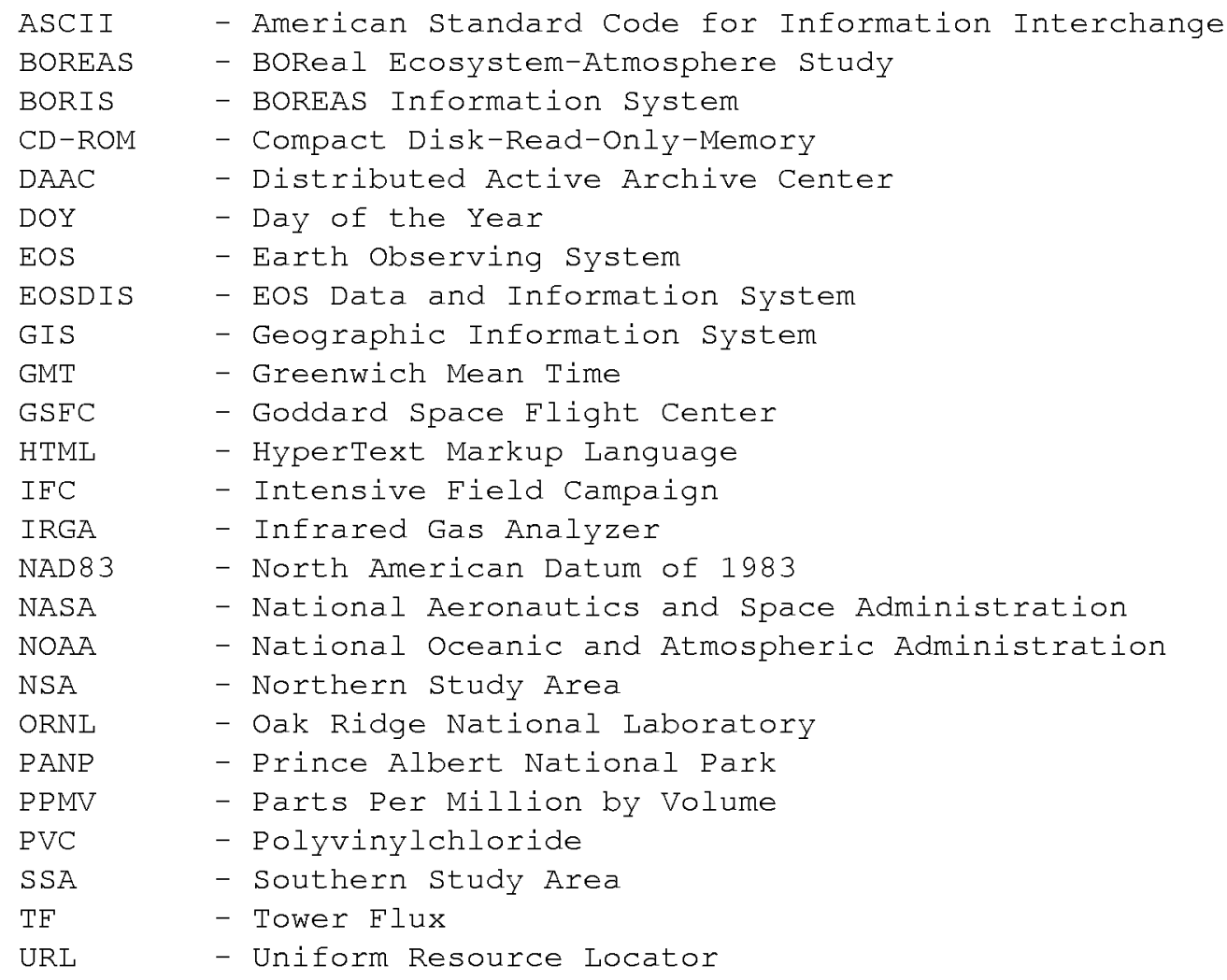

\section{Document Information}

\subsection{Document Revision Date}

Written: 30-Jun-1997

Last Revised: 13-Sep-1999

\subsection{Document Review Date(s)}

BORIS Review: 19-Apr-1999

Science Review:

\subsection{Document ID}




\subsection{Citation}

When using these data, please acknowledge T.J. Arkebauer and E.C. Jolitz and include citations of relevant papers in Section 17.2.

If using data from the BOREAS CD-ROM series, also reference the data as:

Arkebauer, T.J. and S.B. Verma, "Field Micrometeorological Measurements, Process-Level Studies and Modeling of Methane and Carbon Dioxide Fluxes in a Boreal Wetland Ecosystem (SSA-Fen)." In Collected Data of The Boreal Ecosystem-Atmosphere Study. Eds. J. Newcomer, D. Landis, S. Conrad, S. Curd, K. Huemmrich, D. Knapp, A. Morrell, J. Nickeson, A. Papagno, D.

Rinker, R. Strub, T. Twine, F. Hall, and P. Sellers. CD-ROM. NASA, 2000.

Also, cite the BOREAS CD-ROM set as:

Newcomer, J., D. Landis, S. Conrad, S. Curd, K. Huemmrich, D. Knapp, A. Morrell, J. Nickeson, A. Papagno, D. Rinker, R. Strub, T. Twine, F. Hall, and P. Sellers, eds. Collected Data of The Boreal Ecosystem-Atmosphere Study. NASA. CD-ROM. NASA, 2000.

\subsection{Document Curator}

\subsection{Document URL}


Public reporting burden for this collection of information is estimated to average 1 hour per response, including the time for reviewing instructions, searching existing data sources, gathering and maintaining the data needed, and completing and reviewing the collection of information. Send comments regarding this burden estimate or any other aspect of this collection of information including suggestions for reducing this burden, to Washington Headquarters Services. Director ate for Information Operations and Reports, 1215 Jefferson Davis Highway, Suite 1204, Arlington, VA 22202-4302, and to the Office of Management and Budget, Paperwork Reduction Project (0704-0188), Washington, DC 20503.

\begin{tabular}{l|l|l|}
\hline 1. AGENCY USE ONLY (Leave blank) & 2. REPORT DATE & 3. REPORT TYPE AND DATES COVERED
\end{tabular}

\begin{tabular}{l|l|l|} 
& November 2000 & Technical Memorandum \\
\hline
\end{tabular}

4. TITLE AND SUBTITLE

5. FUNDING NUMBERS

Technical Report Series on the Boreal Ecosystem-Atmosphere Study (BOREAS)

BOREAS TF-11 SSA-Fen Soil Surface $\mathrm{CO}_{2}$ Flux Data

\section{AUTHOR(S)}

Timothy J. Arkebauer

Forrest G. Hall and David E. Knapp, Editors

7. PERFORMING ORGANIZATION NAME(S) AND ADDRESS (ES)

Goddard Space Flight Center

Greenbelt, Maryland 20771

923

RTOP: $923-462-33-01$
9. SPONSORING / MONITORING AGENCY NAME(S) AND ADDRESS (ES)

National Aeronautics and Space Administration

Washington, DC 20546-0001
8. PEFORMING ORGANIZATION REPORT NUMBER

2000-03136-0

\section{SUPPLEMENTARY NOTES}

T.J. Arkebauer: University of Nebraska-Lincoln;

D.E. Knapp: Raytheon ITSS, NASA Goddard Space Flight Center, Greenbelt, Maryland

\begin{tabular}{l|l}
\hline 12a. DISTRIBUTION / AVAILABILITY STATEMENT & 12b. DISTRIBUTION CODE \\
Unclassified-Unlimited & \\
Subject Category: 43 & \\
Report available from the NASA Center for AeroSpace Information, \\
7121 Standard Drive, Hanover, MD 21076-1320. (301) $621-0390$.
\end{tabular}

13. ABSTRACT (Maximum 200 words)

The BOREAS TF-11 team gathered a variety of data to complement its tower flux measurements collected at the SSA-Fen site. These data are soil surface $\mathrm{CO}_{2}$ flux data at the SSA-Fen site from $27-$ May-1994 to 23-Sep-1994 and from 13-May-1995 to 03-Oct-1995. A portable gas exchange system

was used to make these measurements. The data are stored in tabular ASCII files.

14. SUBJECT TERMS

BOREAS, tower flux, soil surface data.
10. SPONSORING / MONITORING AGENCY REPORT NUMBER

TM-2000-209891

Vol. 216

\begin{tabular}{|l|l|} 
& \\
\hline $\begin{array}{l}\text { 17. SECURITY CLASSIFICATION } \\
\text { OF REPORT }\end{array}$ & $\begin{array}{c}\text { 18. SECURITY CLASSIFICATION } \\
\text { OF THIS PAGE } \\
\text { Unclassified }\end{array}$ \\
\hline
\end{tabular}

19. SECURITY CLASSIFICATION OF ABSTRACT

Unclassified
15. NUMBER OF PAGES

15

16. PRICE CODE
20. LIMITATION OF ABSTRACT

UL 
